\title{
Managed Aquifer Recharge: An Overview of Issues and Options
}

\author{
Joël Casanova, Nicolas Devau, and Marie Pettenati
}

\begin{abstract}
As covered in Chap. 2, many of the world's aquifers are rapidly being depleted. Nearly one quarter of the world's population -1.7 billion people - live in regions where more water is being consumed than nature can renew (Gleeson et al. 2012). Over-exploitation occurs when groundwater abstraction is too intensive, for example for irrigation or for direct industrial water-supply like extracting fossil fuels (Pettenati et al. 2013; Foster et al. 2013). When groundwater is continuously over-pumped, year after year, the volume withdrawn from the aquifer cannot be replaced by recharge. Eventually, the groundwater level is much lower than its initial level and even when pumping stops, the aquifer has trouble rising once again to its original level. In continental zones, overexploitation can lead to groundwater drawdown and, ultimately, to subsidence through development of sinkholes when underground caverns or channels collapse. In coastal areas, the decrease in groundwater recharge results in saltwater intrusion into the aquifer formation (Petalas and Lambrakis 2006; De Montety et al. 2008). Preserving local groundwater resources is an environmental and economic issue in coastal zones and is vital in an island context. The increasing demand for water caused by a growing population can lead to the salinization of groundwater resources if these are systematically over-exploited. Limiting the salinization of coastal aquifers is consistent with the groundwater objective of the European Union Water Framework Directive, which is to achieve a good qualitative and quantitative status by 2015 . The economic advantage of preserving these threatened water resources is that, when there is a growing demand, a local water resource is sustained and there is no need to import water. Transporting water can cost 2-10 times more than limiting the intrusion of saltwater into a coastal aquifer.
\end{abstract}

J. Casanova $(\bowtie) \cdot$ N. Devau $\bullet$ M. Pettenati

BRGM, Orléans, France

e-mail: j.casanova@brgm.fr 


\subsection{Introduction}

As covered in Chap. 2, many of the world's aquifers are rapidly being depleted. Nearly one quarter of the world's population -1.7 billion people - live in regions where more water is being consumed than nature can renew (Gleeson et al. 2012). Over-exploitation occurs when groundwater abstraction is too intensive, for example for irrigation or for direct industrial water-supply like extracting fossil fuels (Pettenati et al. 2013; Foster et al. 2013). When groundwater is continuously overpumped, year after year, the volume withdrawn from the aquifer cannot be replaced by recharge. Eventually, the groundwater level is much lower than its initial level and even when pumping stops, the aquifer has trouble rising once again to its original level. In continental zones, over-exploitation can lead to groundwater drawdown and, ultimately, to subsidence through development of sinkholes when underground caverns or channels collapse. In coastal areas, the decrease in groundwater recharge results in saltwater intrusion into the aquifer formation (Petalas and Lambrakis 2006; De Montety et al. 2008). Preserving local groundwater resources is an environmental and economic issue in coastal zones and is vital in an island context. The increasing demand for water caused by a growing population can lead to the salinization of groundwater resources if these are systematically overexploited. Limiting the salinization of coastal aquifers is consistent with the groundwater objective of the European Union Water Framework Directive, which is to achieve a good qualitative and quantitative status by 2015. The economic advantage of preserving these threatened water resources is that, when there is a growing demand, a local water resource is sustained and there is no need to import water. Transporting water can cost 2-10 times more than limiting the intrusion of saltwater into a coastal aquifer.

All over the world, the problems related to groundwater withdrawal from coastal aquifers are usually complicated because they associate the notion of quantity with that of quality (Werner et al. 2013). They are even more complex given that there is often a high demand for water in coastal areas. Population growth and the development of agriculture, industry and tourism are leading to increased groundwater abstraction, while the effects of global climate change are increasing seasonal variations. The deterioration of groundwater quality and quantity as demand increases is becoming more pronounced. In order to prevent this salinization, long-term operational management measures must be taken.

In such various contexts, technologies for Managed Recharge Aquifer (MAR) are of particular interest (see also Chap. 17). Indeed, these technologies aim to increase the available quantities of groundwater by increasing groundwater infiltration to aquifer formations. Together with rain, treated wastewater and desalinated seawater, it is one of the unconventional sources of water that is most often included in integrated water management schemes. MAR is one of the measures that can be implemented to secure water supply, compensate for some effects of climate change and, more generally, handle the quantity and quality of groundwater bodies. It is not, however, a substitute for groundwater management based on decreasing abstraction and adapting withdrawal to resource availability. 
Due to its relatively high cost (Khan et al. 2008), MAR has been practised, over the last four decades, mainly in developed countries. It is commonly carried out in the United States, and now increasingly in Europe (Levantesi et al. 2010). Large cities, especially, most often use this management method (Berlin, Paris suburbs, Lyon, Dunkirk, Geneva). In these cities, MAR is used to manage stormwater by collecting surface runoff waters in infiltration basins. However, stormwater can be one of the main sources of pollutants (heavy metals, hydrocarbons and other organic compounds) produced by cities. Consequently, traditional urban drainage systems now cause many technical and environmental problems, notably the pollution of the surface receptor media (Chocat et al. 2007). Nevertheless, some MAR technologies can also be used to limit the pollution of surface water by infiltrating some of the polluted water and monitoring the geo-purification and/or attenuation processes. Therefore, MAR can also be undertaken to protect the environment by limiting the level of pollution in sensitive receptor media. In Mediterranean countries, MAR has in some cases been taken into account in reservoir design in order to limit losses by evaporation. In coastal contexts, the MAR objective is to move from passive management of saltwater intrusion (by reducing abstraction for the drinking water supply) to dynamic management optimising pumping and natural and artificial recharge as a function of aquifer model predictions and the results of continuous, in-situ monitoring of the water table. The principal objective of MAR here is to create a hydraulic barrier to prevent the intrusion of pollutants and saltwater (Casanova et al. 2007, 2008).

Based on the large number of existing reviews already published about MAR technologies (e.g. Dillon et al. 2009a, b; Page et al. 2010; Chap. 17), the present book chapter summarizes the main managed recharge measures (types of artificial recharge systems, hydrogeological and regulatory restrictions, health and environmental risks) and makes recommendations concerning site selection, technical feasibility and monitoring methods. As an illustrative purpose of MAR technologies, there is a focus on French MAR installations.

\subsection{MAR Technologies}

\subsubsection{Infiltration Methods}

Infiltration methods are designed to facilitate the infiltration of water to the aquifer by means of infiltration basins (ponds, tanks), while improving the quality of the recharge water by natural attenuation in the aquifer's unsaturated zone. They are usually used to recharge water table aquifers or, in some cases, to create hydraulic barriers. One of the main advantages of these methods is that they are inexpensive and relatively easy to implement and maintain. The "infiltration ponds" method includes installations such as dams and small reservoirs, as well as various improvements and installations designed to manage stormwater (or runoff) and individual wastewater treatment units. This category also includes reservoir 
pavements, recharge pits, drainage trenches, vegetated ditches, mounds systems, sand filters and septic drain fields.

With all of these techniques, the water passes through the unsaturated zone before reaching the aquifer. The water can thus be potentially purified by contact with the soil, which enables the elimination not only of certain pathogenic agents but also of potentially harmful inorganic and organic substances. Infiltration ponds are often used in MAR projects, notably in places where there are frequent water shortages. Depending on which technique is being considered (infiltration ponds, percolation tanks, Soil Aquifer Treatment (SAT) Dillon 2005), basin characteristics such as the desired infiltration rate are adapted to the local objectives and can vary significantly. If the objective is quantitative, the chosen infiltration rate might be relatively high (several meters per day), whereas a lower infiltration rate (an average of $0.5 \mathrm{~m} . \mathrm{day}^{-1}$ ) would be recommended when the objective also includes the geo-purification of the infiltrating water.

The geo-purification capacity of the filtering layer is in some cases improved when plants are grown on this layer. Indeed, the presence of plants in the filtering layer protects the surface of the basin from erosion and clogging and is carriers for bacteria that act for biodegradation of some inorganic and organic pollutants. On summer, plants can improve the purification of the infiltrated water by enhancing phytoremediation.

The water temperature also has an influence on the infiltration rate. Colder water infiltrates more slowly due to an increase in viscosity. The volume of water that infiltrates below a basin can therefore decrease significantly in winter. Water that has not been greatly treated is also rich in organic matter, which fosters the development of bacteria. This might decrease the porosity, notably by the formation of biofilms.

To avoid, or rather slow down this clogging process several processes are available, depending on the application (Le Coustumer 2008). The first is to pre-treat the water that will infiltrate. Settling ponds or sand filters can be installed upstream from the infiltration basin, or the chemical properties of the recharge water can be modified by adding various chemical compounds, mostly inorganic. The second solution is to operate infiltration basins alternately, following "wetting-drying" cycles, in order to enable the decompacting and/or maintenance of the basin floor.

\subsubsection{Direct Injection Method}

Direct injection methods using injection wells are the methods most often used throughout the world. Aquifer Storage and Recovery (ASR) and Aquifer Storage Transfer and Recovery (ASTR) are installed mainly to meet two objectives: (i) to recharge confined (or semi-confined) aquifers and/or (ii) to create hydraulic barriers. The quality of the injected water must be closely monitored to prevent any contamination. They might also be preferred when space is limited because their footprint, only several tens of $\mathrm{m}^{2}$, is small compared to that of infiltration basins. Moreover, their wellhead protection zone is small. 
The principle behind ASR is the injection of water into an aquifer followed by its recovery by pumping from the same well at a later date. This method involves distinct and alternating periods of storage of excess water and of its consumption (Pyne 2006). ASR is therefore generally used for aquifers that are relatively invulnerable to non-point source pollution and in which groundwater moves slowly, i.e. confined or semi-confined aquifers. This method is used mainly for the seasonal storage of good quality water (sometimes potable), as a "pocket of fresh water" in an aquifer containing non-potable water. From a technical point of view, there are two advantages to this method. First of all, it entails alternating phases of injection and abstraction in the same well. This results in an inversion of the water circulation in the well screen and in the surrounding aquifer, thereby reducing clogging (Dillon et al. 2006; Pyne 2005, 2006). Secondly, the use of the same well for injection reduces investment costs.

As opposed to ASR, ASTR involves injection in one well and recovery by pumping from a second well located several hundred metres down-gradient from the injection well. The injected water is transferred through the aquifer before being abstracted. The specific technical characteristics of this set up require that the water in the aquifer be of relatively good quality. ASTR is therefore used mainly when the pumped water is a supply for human consumption.

\subsubsection{Filtration Methods}

Induced recharge called riverbank filtration, involves increasing the infiltration of water from a river to its alluvial aquifer by pumping in wells located near the riverbank. A string of wells are installed parallel to and near the river. Pumping in the wells lowers the water table, creating a difference in head between the river and the groundwater. This draws the surface water through the riverbank, as long as the riverbank is not clogged and/or the pumping rate is sufficient. The principal aim of this technology is to use the geo-purifying capacity of the riverbank to filter and purify the recharge water. Due to the high concentration of suspended matter in surface water, riverbanks rapidly become clogged. In order to prevent this, the infiltration rate must be relatively low and the riverbanks must be periodically maintained. Another method called dune filtration consists of infiltrating water from ponds constructed in dunes. The water is then extracted from wells or ponds at lower elevation (Dillon 2005).

\subsection{Sources of Water Used for MAR}

The first basic criterion concerning the feasibility of a MAR project is the availability of recharge water near the injection site in order to ensure a steady supply and limit potential transport costs. An aquifer can be recharged with several types of 
water. Several types of water are used for recharge: surface water from rivers, stormwater and treated wastewater.

The inventory of MAR installations still active in France showed that almost all of these use surface water, notably due to the availability of this resource. Indeed, surface water is abundant in temperate countries where rainfall adequately replaces water lost by evapotranspiration and flow to the sea. There are three other reasons for the predominant use of surface water. Firstly, the chemical and microbiological quality of this water is adequate, even when the water is not pre-treated, which enables its use for both quantitative and/or qualitative objectives. Secondly, surface water can be used with different existing MAR techniques, from infiltration or indirect injection to direct injection. Thirdly, the laws that enable the use of surface water for recharge systems already exist.

Intermittent surface water bodies can also be used, although their hydrological cycle is somewhat random and water availability depends on climate events that only occur over several days or weeks each year. It is important to note that the duration of these climate events can vary from year to year. Historically, this type of surface water has been little used for MAR due to its intermittent character. Recently, new techniques, notably for direct injection, have been developed in order to use this type of water. Most of these are new ASR techniques developed in semi-arid and arid Mediterranean climate zones.

Desalinated water made from seawater or brine is an alternative. First developed to produce drinking water, industrial water and water for agriculture, desalinated water can also be used for MAR. Initially used only in energy-rich countries like Saudi Arabia, the United Arab Emirates or Bahrain (Ahmed et al. 2001; Al-Zubari 2003; Chafidz et al. 2014), all of which produce drinking water from seawater, desalinated water is increasingly used elsewhere in the world thanks to improved desalination techniques that have decreased production costs (Shatat et al. 2013; Feitelson and Rosenthal 2012; Moatty 2001; Palomar and Losada 2010). Because of the relatively small quantities produced and their very high cost (Dabbagh 2001), desalinated water is almost never used for MAR, the aim of which is to significantly increase the volume of groundwater. However, the stability of desalinated water production might be a favourable argument for its use in some arid countries as a secondary source of recharge water for installations whose objective is quantitative. Desalination techniques confer particular chemical properties on this type of water. The principal characteristic is that it contains very little salt. When water is produced by distillation, it usually has a dissolved salt content of between 5 and $30 \mathrm{mg} . \mathrm{L}^{-1}$. Due to its low salt content, this water does not meet drinking water standards. It is therefore necessary to remineralize it until its salt content reaches ca. 300 mg. $\mathrm{L}^{-1}$.

At present, treated wastewater is used in MAR systems in many countries. Although very common in countries with limited water resources, wastewater is rarely reused in France (about 40 projects developed experimentally for irrigating crops, watering golf courses and forests or prairies) and there are no MAR installations that specifically use treated urban wastewater. It is important to point out that in France the use of wastewater for MAR is forbidden (Miquel 2003). 
The volumes of reclaimed treated wastewater are slightly higher than those of desalinated water but are still lower than those of surface water. Like that of desalinated water, the production of treated wastewater is relatively stable over time. It is, however, important to point out that the production of wastewater increases drastically during tourist seasons in holiday resorts. Therefore, treated wastewater is usually used for both recharge systems whose objective is to significantly increase the volume of groundwater and those whose objective is to improve groundwater quality.

In this context, MAR using infiltration of treated wastewater might be one of the possible solutions for recycling water to its natural medium while making it possible, for example, to recharge over-exploited aquifers, prevent saltwater intrusion into coastal aquifers, or store water without the loss by evaporation that occurs in open-air reservoirs, and make it available during periods of high demand. Treated wastewater is therefore an alternative resource that is available throughout the year and, in particular, during low water stages when the demand for conventional resources is highest, or when they are unavailable. It is of particular interest when the natural resource is scarce, notably in coastal areas and on islands. Moreover, the infiltration of treated wastewater through an unsaturated zone to recharge an aquifer benefits from the purifying capacity of the sub-surface in which naturally occurring processes enable the degradation or filtering of a certain number of the water's pollutants (Bekele et al. 2011).

Industrial water comes from factories, manufacturing plants and farms. The discharge of this water is subject to a specific study and preliminary treatment is usually required. It can contain both easily degradable organic compounds and substances that do not degrade easily such as organohalogenated compounds or heavy metals. Compared to treated urban wastewater, industrial water which contains more specific contaminants (organic molecules, trace metals and contaminants of emerging concern (CECs)) is generally not used for MAR. Indeed, most companies have their own treatment plants to treat the specific effluents of their industrial processes. This means that this water is not systematically discharged to the municipal wastewater system, thus limiting its use. However, this water can be used for MAR if there is a system to route the water to the MAR site and its chemical quality has been specifically studied.

\subsection{Hydrogeological and Regulatory Constraints}

The feasibility of an MAR system depends for the most part on local hydrogeological conditions (Dillon 2005). In the case of infiltration methods, the unsaturated zone must allow the water to infiltrate to the aquifer and the aquifer must be able to store the infiltrated water. Preference is therefore given to sites that have a rather low diffusivity, i.e. relatively low permeability and high storage capacity. These conditions can be found in aquifer formations with interstitial porosity (e.g. sandy, sandstone formations) or with both interstitial and fracture 
porosity (e.g. chalk). As concerns water quality, when choosing an MAR site, one must be sure that the quality of the recharge water is compatible with the reactive potential of the aquifer matrix and especially that of the unsaturated zone.

Current French regulations state that an MAR system is subject to prior approval in compliance with the environmental code and an impact assessment must be carried out. It must comply with French and European water laws, in particular with respect to the prevention and mitigation of discharge of pollutants to groundwater. In the specific case of MAR systems, the environmental code prohibits the use of treated wastewater in France.

Wells used to supply drinking water can be located down-gradient of the sector targeted for MAR with water whose quality is degraded. It is therefore essential that the safety for public health and the environment of the artificial recharge, induced by the addition of water to a parcel and its transport to the aquifer through the unsaturated zone, is ensured. The regulatory "wellhead protection zone" tool, described in the French public health code (Water law of the 3th January 1992, article L-1321-2) is, in most hydrogeological contexts, poorly suited to preventing pollution. Additional measures have therefore been taken in protection zones. These must now be implemented at the scale of an entire well or well-field catchment area, which is the most appropriate spatial unit for combating nonpoint source pollution (Vernoux et al. 2010). If this catchment area includes an MAR installation, the restrictions on the quality of the infiltrated water are even stricter.

\subsection{Health and Environmental Risks}

Depending on the quality and the efficiency of the treatments given to the recharge water, it can contain various amounts of pollutants such as trace metals, nutrients and microorganisms, including pathogenic microorganisms and contaminants of emerging concern (CECs) (Lapworth et al. 2012). Using different waters that have different origins and different qualities, notably treated wastewater, for MAR systems might therefore create high risks for public health. The complexity of reactive transport processes in the unsaturated zone highlights two of the main stumbling blocks that must be taken into consideration if treated wastewater is being considered for MAR: one specific challenge is to have numerical models that can include all of the hydro-biogeochemical processes involved in reactive transport, while a second, more operational, is the need to have a complete biogeochemical and hydrogeological characterisation specific to each MAR site.

\subsubsection{Trace Metals}

The problem posed by metals in recharge water concerns first of all the use of treated wastewater since the concentrations of many trace metals are very low in 
most natural waters. Several studies have shown that trace metal concentrations can vary greatly in runoff and surface water but that, except for iron and lead, they are, the most part of the time, below acceptable levels (Haeber and Waller 1987). Iron and lead present relatively few health risks. Recharge water coming from water treatment plants might also contain trace metals, the most abundant of which are iron, zinc, copper and lead. Other trace metals can also be found: manganese, aluminium, chrome, arsenic, selenium, mercury, cadmium, molybdenum, nickel, etc. They are of various origins. They come from products consumed by the population at large, from the corrosion of material in the water distribution and treatment systems, from service activities (health, automobile) and possibly from industrial effluents (Cauchi et al. 1996). Trace metals can be dissolved in recharge water from the aquifer material by modification of natural geochemical conditions. The recharge water, rich in nutrients and organic matter leads to the creation of new redox conditions in the system driven by the microbial community (Hunter et al. 1998; Kloppmann et al. 2012; Pettenati et al. 2012).

Several countries (the United States and Australia, for example) have developed guidelines for the use of treated wastewater for recharge (USEPA 2004, 2012; WHO 2006a, b). These guidelines focus mainly on the health and environmental risks that result from the presence of pathogenic microorganisms, suspended solids and dissolved organic carbon in this water. There are few recommendations concerning trace element contents in water (e.g. USEPA 2012), except as concerns five trace metals. These are: (i) arsenic, for which the drinking water limit is $10 \mu \mathrm{g} /$ L in France; (ii) nickel, which is only weakly toxic but which accumulates in plants; (iii) cadmium, which is considered to be the metallic pollutant of greatest concern due to its rapid accumulation in plants and its proven toxicity even at low concentrations (acceptable daily intake (ADI) $0.057 \mathrm{mg} /$ day/individual); (iv) mercury, which can be highly mobile; and (v) lead, the injection of which, even at low doses, can cause neurotoxic and hepatotoxic disturbances (Dillon et al. 2009a).

\subsubsection{Emerging Pollutants}

Water quality and societal wellbeing are currently threatened by emerging pollutants and pathogens including antibiotic resistant bacteria and viruses. The recharge water that is most likely to be contaminated by pharmaceutical products is treated wastewater. Indeed, there are several sources of pharmaceutical products discharged to water bodies. The excretion of pharmaceutical products by patients following their ingestion is the main source of wastewater contamination. Hospital wastewater therefore contains high levels of pharmaceutical products, essentially antibiotics. Moreover, anaesthesia products, disinfectants and diagnostic products are also present in this wastewater.

Some pharmaceutical products in their active forms, and/or their metabolites if these are also active, can be hazardous for the environment from an eco-toxicological point of view. They are then found in wastewater. When wastewater is treated, the elimination of these pharmaceutical products and/or their 
metabolites varies depending on both the nature of the drug under consideration and on the characteristics of the treatment methods used in the treatment plant (Joss et al. 2005; Yu et al. 2006). Furthermore, the elimination of pharmaceutical products does not mean their total destruction. They can degrade into products that are also active (Kümmerer et al. 1997; Zwiener et al. 2002). Several studies have identified the presence of various pharmaceutical products in treated wastewater (Steger-Hartmann et al. 1996; Kümmerer et al. 1997; Ternes et al. 1998). For example, Ternes et al. (1998) showed that the most abundant pharmaceutical products in wastewater are beta blockers, contrast media and pain relief/antiinflammatory drugs.

Like that of trace metals, the mobility of pharmaceutical products can be reduced with infiltration basins and indirect injection methods because the presence of an unsaturated zone enhances the trapping of these pollutants. In the unsaturated zone, geochemical and microbiological processes can indeed decrease the concentration of both pathogenic and non-pathogenic microorganisms and CECs by (i) biodegradation and (ii) adsorption. To a lesser extent, adsorption can also limit the mobility of organic pollutants. Pharmaceutical products can be adsorbed on several solid phases in the unsaturated zone, such as oxyhydroxides, mineralogical clays and humic substances. This adsorption of pharmaceutical products requires the creation of a chemical or electrostatic link between the functional groups present on a pharmaceutical product and the functional groups present on the solid phases in the unsaturated zone. The adsorption of these pharmaceutical products might or might not result in the release of chemical compounds to the aqueous phase.

\subsubsection{Risk Assessment}

At present, most studies have focused mainly on notions of environmental risk (Devaux 1999; Wintgens et al. 2012; Dillon et al. 2009b). These risk assessment studies consider three types of risks: (i) potential theoretical risk, (ii) potential experimental risk, and (iii) real risk.

Potential theoretical risk is related to all of the disruptions that might affect the various characteristics of the aquifer as a result of the installation of an MAR system. These include, for example, groundwater contamination by recharge water that contains pollutants (trace metals, metalloids, microorganisms, pharmaceutical products, etc.). The assessment of theoretical risk therefore requires the determination of: (i) the possible sources of contamination of the recharge water used, such as prolonged contact with minerals rich in trace metals, industrial discharge, or the presence of a nearby hospital; and (ii) the intrinsic chemical and microbiological quality of the recharge water.

Potential experimental risk corresponds to the risk that the disruptions affecting the recharged aquifers might be transferred to humans or to the environment. This experimental risk corresponds, for example, to the probability that a pollutant present in the recharge water will reach humans. In this case, the experimental 
risk will depend not only on the theoretical risk associated with the contamination of the recharge water but also to other factors such as the volumes of recharge water injected, the efficiency of pre-treatments, and the geo-purification capacity of the unsaturated zone in the case of infiltration structures (infiltration basin and indirect injection techniques).

The last type of risk that is considered by studies assessing the impacts of recharge systems is the real risk, which is the probability that one member of an exposed population will be contaminated (Devaux 1999). This risk broadens the notion of potential environmental risks by considering other factors that are specific to individuals exposed to disruptions caused by MAR such as the specific immunesystem capacity of a given individual (natural or acquired), age, sex, health, nutrition, hygiene and the diagnostic ability of health personnel (e.g. serology).

Although many risk assessment studies have made it possible to define the conceptual framework of the risks associated with MAR, the complexity of the developed markers, and the lack of knowledge concerning some of the components of these markers, means that the dangers associated with the disruptions caused by this activity are hard to quantify. For example, the water consumption of individuals, which is needed for assessing the real risk, is difficult to estimate because it can be influenced by many factors such as age or access to drinking water resources.

\subsection{Implementing MAR}

\subsubsection{Hydrogeology Study}

The feasibility of an MAR system depends largely on local hydrogeological conditions (Dillon 2005). Understanding of natural recharge, of its evolution, and therefore of the storage capacity of the sub-surface will be a fundamental criterion for decision support in the choice of an artificial recharge site. This step of feasibility needs a closely hydrogeological analysis with the help of hydrogeologic experts that can advise about the drawbacks or benefit of the future considered MAR site.

\subsubsection{Biogeochemical Processes Evaluation}

In the case of artificial recharge systems that involve infiltration techniques, geochemical and microbiological processes might occur in the unsaturated zone that enables the purification of the recharge water. Furthermore, the unsaturated zone must allow the water to infiltrate to the aquifer, the aquifer must be able to store the infiltrated water, and then release it without excessive "dissipation", which would cancel the storage effect. 
It is, however, possible to identify the main criteria that can affect the geochemical and microbiological processes that enhance the purification of the recharge water as it moves through the unsaturated zone: (i) $\mathrm{pH}$, (ii) redox potential, (iii) organic matter content, and (iv) mineralogy (Johnson et al. 1999; Rinck-Pfeiffer et al. 2000; Pettenati et al. 2012):

(i) In order to limit trace metal mobility and optimize organic contaminant degradation, it is preferable that the $\mathrm{pH}$ of recharge water interacting with the aquifer matrix and/or soil presents a range of values between 5 and 8 . In general, adsorption processes (surface complexation and ion exchange reactions) of cations such as trace metals and degradation reactions are usually weaker at extreme $\mathrm{pH}$ values. Under acidic conditions $(\mathrm{pH}<4)$, the adsorption of protons on negatively charged adsorption sites neutralises the charges of these sites, or even gives them a positive charge, which decreases the adsorption capacity of the components of the medium for cations. Under alkaline conditions $(\mathrm{pH}>8)$, cations do not remain in the form of free ions but form aqueous complexes involving anions, usually the oxyhydroxides group, that are present in the solution.

(ii) Geo-purification processes (adsorption, dissolution/precipitation, biodegradation) are strongly influenced by the redox potential. For example, a decrease in the redox potential can cause dissolution of oxide and/or hydroxide carrier phases and therefore the release of adsorbed trace metals at their surface or in their crystal matrix. Furthermore, a decrease in the redox potential modifies the aqueous speciation of trace metals, which can increase their toxicity (for example, by transforming $\mathrm{As}(\mathrm{V})$ into As(III)).

(iii) The natural attenuation processes occurring in the soil and sub-soil, particularly in the unsaturated zone, have been shown to be quite effective with respect to trace organic removal (Ternes et al. 1998). The biodegradation process is also influenced by organic matter. Organic matter is the main source of energy for microorganisms in the unsaturated zone. In order to enhance the metal adsorption reactions and microbiological reactions including the degradation of organic pollutants or the reduction of nitrates, recharge systems should be installed on sites having significant relatively-insoluble organic matter content.

(iv) Another criterion that makes it possible to evaluate the geo-purification capacities of unsaturated zones during artificial recharge is their mineralogy. Indeed, mineralogy can strongly influence the geochemical processes that control the mobility of pollutants in the unsaturated zone. Analysing the mineralogy of the unsaturated zone makes it possible to determine the concentrations of oxyhydroxides and clay minerals, which are the solid phases that have the greatest affinity for pollutants. 


\subsubsection{Particular Case of SAT: Methodology of Purification Processes Evaluation}

An initial, generic approach should, however, make it possible to roughly identify and quantify the potential biological activity (of the soil itself, or of the injected water) that will play a role in the evolution of the main mineral phases of interest as concerns: the physical and chemical characteristics of the soil (dissolution/precipitation), and on certain global reactions that must be defined (organic matter decomposition, redox reactions of $\mathrm{Fe}, \mathrm{S}, \mathrm{Mn}$, etc.) depending on the nature of the injected water and the soil (Azaroual et al. 2008, 2009; Pettenati et al. 2012).

Once the MAR site has been identified, taking into account constraints such as the availability of water, hydrogeological characteristics and regulations, five steps are usually necessary:

- a preliminary evaluation of the feasibility of a recharge system on the chosen site based on existing data or modelling

- designing the recharge system

- carrying out a detailed study of the site in order to validate or supplement the results obtained in the first step

- building a pilot or experimental system at a scale that makes it possible to carry out preliminary tests

- extrapolation to an operational scale

Since the aim of SAT is to optimise the upstream treatment of residual water and the natural geo-purification of the sub-surface, a preliminary analysis of the chosen site must be carried out since the characteristics of the recharge water and of the mineralogical assemblage making up the sub-surface are site-specific. The water quality monitoring programme recommended by Ollivier et al. (2013) include the following:

- measuring physical-chemical parameters: water saturation, water pressure, temperature, conductivity, redox potential, $\mathrm{pH}$ of the infiltration water

- sampling and analysis of the gas in the unsaturated zone

- sampling and analysis of the water in the unsaturated zone

- sampling of the soil for mineralogical and microbiological analyses

- permeability testing of the soil and sub-soil on the recharge site

\subsubsection{Cost-Benefit Study}

The costs and benefits of the different management solutions (including environmental costs and benefits) must be systematically assessed in close collaboration with hydrogeological study (Shah 2014). The concept of water foot-printing needs to be deepened, establishing practical methods and certifiable systems. Innovative concepts for water resources management need to be developed, with the aim of 
providing science-proof solutions to societal water challenges. On the basis of French feedback (Casanova et al. 2013), the feasibility of implementing MAR strongly depends on developing new approaches for water management aiming at setting up innovative alternatives suitable for decision making. These approaches should be ideally based on: (i) the broad participation of stakeholders; (ii) multidisciplinary research; and (iii) the development of scenarios to support short to long term decision making.

\subsection{Case Study of the MAR in France}

Groundwater can be found in two thirds of France which has about 200 large aquifers and 6,300 small aquifers, and at least 6 billion $\mathrm{m}^{3}$ are withdrawn every year $-59 \%$ for drinking water supply, $19 \%$ for agriculture (irrigation) and $22 \%$ for industry (not including the water used by nuclear power plants) (SOeS 2012). When there is a rainfall deficit for several successive years (e.g. between 2006 and 2011), or during periods of long summer drought particularly in the southern half of France (Giuntoli et al. 2013), groundwater levels drop significantly, in particular in aquifers that are near the surface and in the large aquifers in the Paris Basin. These critical periods are usually limited in time and space.

Water resources are a crucial element in the analysis of the impacts of climate change and the suitable responses that can be proposed (Roux 1995). Indeed, climate change directly modifies both the spatial and temporal dynamics of the water cycle. The aim of the French National Plan for Adaptation to Climate Change (PNACC) is to develop concrete and operational measures to prepare France, over the next 5 years, between 2011 and 2015, for confronting and even benefitting from new climate conditions (MEDDE 2011).

The impacts of climate change on water resources are numerous (see Chap. 5) and concern both the offer and the demand, both quantitatively and qualitatively (Armandine Les Landes et al. 2014). Climate change predictions indicate that surface runoff will decrease in almost all of France's catchment basins. In particular, the decrease in runoff will be greater in areas that are already affected by structural deficits. Therefore, one of the main challenges of the future will be how to ensure the water supply that, already in some places, is not adequate and will increase due to global warming (IPCC 2014).

The Explore 2070 project aimed to determine the impacts of climate change on aquatic environments and water resources between now and 2070 in order to anticipate the main challenges to be met and rank the risks incurred (MEDDE 2013). As concerns groundwater hydrology, this project showed that there will be an almost universal lowering of the water table in France together with a 10-25\% decrease in recharge, with two zones more severely affected - the Loire catchment basin with a 25-30\% decrease in recharge over half of its surface area, and especially the Southwest of France with decreases ranging from 30-50\%. 


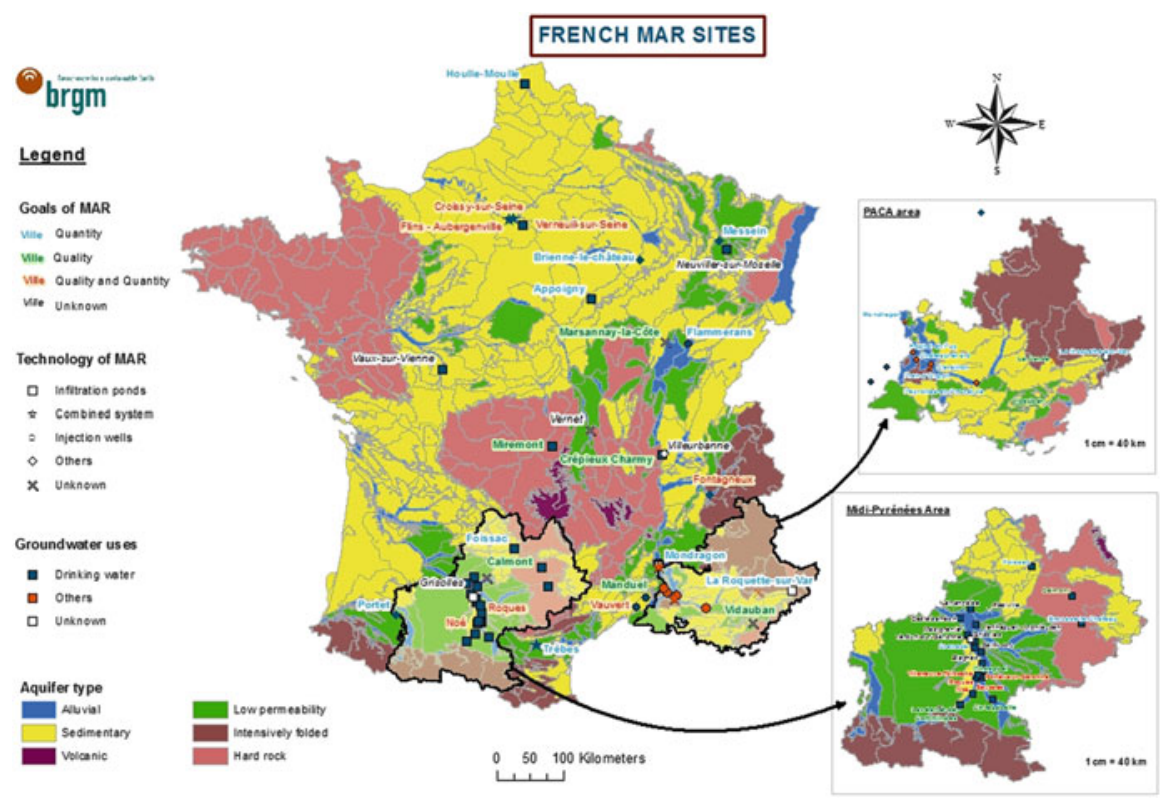

Fig. 16.1 State of MAR facilities in France

The integrated management of water resources by catchment basins must be done comprehensively, taking into account various water needs, including those of the environment. At present, it aims, within the framework of water development and management directives, to reach the objectives of the European Water Framework Directive (WFD, Directive 2000/60/EC of the European Parliament establishing a framework for Community action in the field of water policy). The anticipated impacts of climate change will affect, first of all, regions that are already encountering conflicts over water resources. It is therefore necessary to begin immediately to prevent all situations of diminishing water resources and develop strategies that promote water conservation and optimised use. MAR is one of the tools that can be used for an integrated quantitative (and/or qualitative) management of ground- and surface water resources.

A recent inventory of MAR facilities in France (Casanova et al. 2013) enabled us to identify 75 installations. The current operational status of 48 of these is known with certainty, while there is some uncertainty concerning the operational status of 8 others, and the state of 19 sites could not be determined. Two thirds of the first group are located in the Nord-Pas-de-Calais, Midi-Pyrenees and PACA regions and only about 20 of these are still active today (Fig. 16.1). Many sites have been abandoned when towns find other sources of water for their drinking water supply. In some cases, MAR was no longer needed or the quality of the recharge water no longer enabled the system to function correctly.

In most of the cases identified in France (Casanova et al. 2013), the main objective of MAR is to sustain an over-exploited groundwater aquifer. The second 
objective is to improve the quality of the groundwater by significantly decreasing the concentrations of some chemicals by dilution (e.g. nitrate, pesticides), thereby enabling the use of simpler and cheaper water treatment methods to reach drinking water standards. More precisely, in France, the objective most often sought in MAR projects is quantitative. More than half of the sites inventoried by Casanova et al. (2013) had a quantitative objective, a quarter of them had no clearly defined objective, while the others aimed at improving water quality or had an objective that was both qualitative and quantitative.

MAR is also undertaken to protect the environment by limiting the level of pollution in sensitive receptor media. In 2009, $41.4 \%$ of France's surface water bodies was assessed as having a good ecological status and $43.1 \%$ a good chemical status. In addition, $58.9 \%$ of its groundwater bodies possessed a good chemical status and $89.4 \%$ a good quantitative status (MEDDE 2012a). The quality of France's groundwater is better than that of its surface water $(60 \%$ of the groundwater bodies in France and $80 \%$ in Europe having "good" chemical status). For this reason, groundwater is often used as a source of drinking water. However, the number of French groundwater bodies that have been disqualified for drinking water supply due to nitrates and pesticides is rather large (higher than the European average, the cause of the poor status being divided equally between pesticides and nitrates) (MEDDE 2012b). In France, MAR is therefore often used to dilute pollution in groundwater bodies that are tapped for drinking water such as the MAR installation of Lavelanet-de-Commingues (Haute Garonne, France). This MAR is assigned to decrease the nitrate concentration $\left(>50 \mathrm{mg} \mathrm{l}^{-1}\right)$ of groundwater. Recharge water is abstracted from the upstream Tuchan canal and transport to the water catchment in decantation ponds previous to infiltration ponds. This system permits to maintain a nitrate concentration in the groundwater around $30 \mathrm{mg} \mathrm{l}^{-1}$ (Wuilleumier and Seguin 2003).

Conversely, in France, MAR can also be used to limit the pollution of surface water by infiltrating some of the polluted water and monitoring the geo-purification processes. MAR is used to manage stormwater in many French cities where surface runoff is collected in infiltration basins. However, stormwater is one of the main sources of pollutants (heavy metals, hydrocarbons and other organic compounds) produced by cities. In consequence, traditional urban drainage systems now cause many technical and environmental problems, notably the pollution of the surface receptor media (Chocat et al. 2007).

\subsection{Conclusions}

Recurrent water resources crises call for a better understanding of hydrological processes and improved technical and socioeconomic groundwater management. In many areas of Europe, including France, growing freshwater scarcity currently emphasizes the need to close the water cycle gap by reconciling water supply with demand both in quantity and quality terms. The demand for closed water 
systems is obvious in semiarid areas, where research institutes are currently developing new concepts and technologies. MAR is one of the strategies that can be used for quantitative and qualitative water management and adaptation to climate change in the field of water resources. The various methods used at the sites currently in activity in France and elsewhere in the world use technologies that, for the most part, have been relatively well perfected over the last 20 years.

Water resources observation and modelling are required to better understand hydrological processes and to analyse and forecast the effect of management options. This technological and environmental research must be systematically combined with a socio-economic approach investigating the questions of participation, behaviour and commitment of stakeholders. The choice of a method for artificial recharge depends on numerous factors such as the objective (quantitative and/or qualitative), the local hydrogeological context, the type and volume of recharge water available, and the chemical and microbiological characteristics of this water. Laws regulate the construction and operation of recharge systems. One criterion common to all identified artificial recharge French sites is that they have all been built using a multi-step procedure. Independently of the social, economic and environmental impact that must be taken into account, this chapter highlights the challenge that must be overcome upstream of any regulatory modifications that aim to facilitate the use of these technologies.

Because of the specific local characteristics of each MAR site (Fig. 16.2), there is no universal solution that can be recommended and any change in laws must take this into account. It seems, however, possible to break down artificial recharge installations into two groups based on the quality of recharge water. Water whose quality is similar to drinking water standards is better-suited to direct or indirect injection into the aquifer, whereas for water whose quality is degraded, preference should be given to infiltration methods that enhance additional natural treatment in the subsurface. In both cases, post-treatment, the intensity of which depends on the foreseen use of the pumped water, is necessary before distribution.

Therefore, the initial objective is often to sustain an over-exploited aquifer with other induced benefits such as improved groundwater quality with a significant decrease in the concentrations of some reactive chemicals (i.e. iron, manganese, ammonium, nitrate, organic pollutants, etc.). This enables the use of simpler and cheaper water treatment methods to reach drinking water standards. At the same time, the contamination of the infiltrated water can be reduced naturally if the procedure used to site the installation includes the identification of reactive zones and/or buffer zones and zones that are favourable to the development of microorganisms. Indeed, clay minerals, iron and manganese hydroxides, and microorganisms present in the different zones have great capacities for decontaminating (i.e. biodegradation of organic compounds, etc.) and fixing metallic pollutants and metalloids. Choosing a MAR site therefore requires that the quality of the recharge water is compatible with the soil's reactive processes, especially in the unsaturated zone. In this context, the final treatment of the water might be optimised and hence become less costly. 


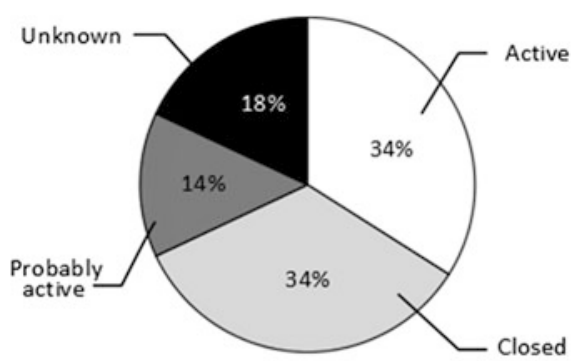

State of the french MAR sites

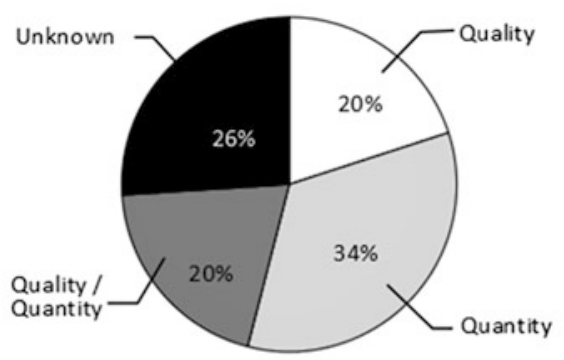

Goals of the french MAR sites

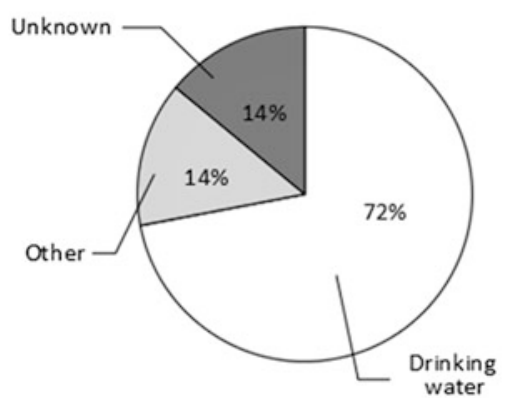

Use of groundwater in the french MAR sites

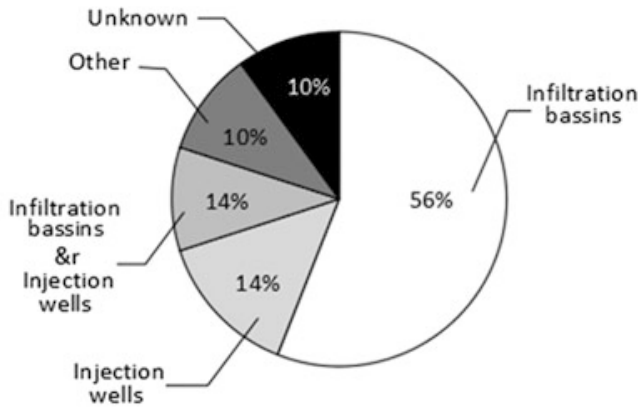

MAR tehcnologies in the french sites

Fig. 16.2 Characteristics of the French MAR sites

In order to meet WFD challenges, links between pressures and water resources have to be established through research activities aiming at elucidating specific connections between water resources, pressures and uses. The combination of observations and hydrological modelling (water bodies, overland flow, unsaturated zone, groundwater and land cover) might be targeted to ensure proper conceptualization of the involved processes. In Europe MAR implementations are being widely reapplied and developed using current technologies. However, French examples of quantified assessments of their effectiveness are limited. Improved understanding of how recharge structures actually function and the impact they have on water availability, water quality, sustainability as well as on the local and downstream environment, need to be gained and disseminated to promote cost-effective implementation.

It is generally assumed that MAR systems will be used throughout the world, including in France, due to the fact that MAR is a pragmatic and potentially 
eco-responsible response to climate change, and our need to adapt to it in a systemic approach to environmental management. Moreover, it is economically attractive for water resource management. It is however difficult to quantify the exact cost of the construction, use and profitability of these systems. Regardless of which technical solution is chosen for recharge, the costs of pre- and/or post-treatment depend strongly on the quality of the injected water. Systems that give preference to slow infiltration and an optimisation of the geo-purification capacities of the sub-surface, therefore, make it possible to minimise the costs inherent in recharge water treatment and enhance the profitability of the project.

Open Access This chapter is distributed under the terms of the Creative Commons AttributionNoncommercial 2.5 License (http://creativecommons.org/licenses/by-nc/2.5/) which permits any noncommercial use, distribution, and reproduction in any medium, provided the original author(s) and source are credited.

The images or other third party material in this chapter are included in the work's Creative Commons license, unless indicated otherwise in the credit line; if such material is not included in the work's Creative Commons license and the respective action is not permitted by statutory regulation, users will need to obtain permission from the license holder to duplicate, adapt or reproduce the material.

\section{References}

Ahmed M, Shayya WH, Hoey D, Al-Handaly J (2001) Brine disposal from reverse osmosis desalination plants in Oman and the United Arab Emirates. Desalination 133(2):135-147

Al-Zubari WK (2003) Assessing the sustainability of non-renewable brackish groundwater in feeding an RO desalination plant in Bahrain. Desalination 159(3):211-224

Armandine Les Landes A, Aquilina L, De Ridder J, Longuevergne L, Pagé C, Goderniaux P (2014) Investigating the respective impacts of groundwater exploitation and climate change on wetland extension over 150 years. J Hydrol 509:367-378

Azaroual M, Lassin A, Pettenati M, André L, Casanova J, Rampnoux N (2008) Reactive transport simulation of the pollutant transfer through the unsaturated soil zone in the framework of an aquifer artificial recharge process. In: Proceedings of "Water Down Under 2008", IBSN 0858 25735 1, Engineers Australia, Apr 2008, p 12

Azaroual M, Pettenati M, Casanova J, Rampnoux N (2009) Reactive transport modelling of pollutant transfer through the unsaturated soil zone in the framework of the artificial recharge of an aquifer under seawater intrusion constraints. In: Proceedings of "REUSE09", Brisbane, 22-25 Sept 2008, p 3

Bekele E, Toze S, Patterson B, Higginson S (2011) Managed aquifer recharge of treated wastewater: water quality changes resulting from infiltration through the vadose zone. Water Res 45 (17):5764-5772

Casanova J, Rampnoux N, Lauras P (2007) Le projet REGAL (REcharge artificielle et Gestion Active des nappes Littorales): une réponse adaptée à l'impact des changements climatiques dans le Sud de la France. Résumé in: L'impact des Changements Climatiques sur les Régions Arides et Semi Arides, 15-17 Décembre 2007, Biskra, Algérie, p 1

Casanova J, Béchu E, Bouzit M, Leroy P, Maton L, Pettenati M (2008) Appui au projet de REcharge artificielle et Gestion Active des nappes Littorales (REGAL). Rapport intermédiaire BRGM/RP - 56836 Ŕ FR, Décembre 2008, 63 pages, 20 illustrations 
Casanova J, Cagnimel M, Devau N, Pettenati M, Stollsteiner Ph (2013) Recharge artificielle des eaux souterraines: état de l'art et perspectives. Rapport final. BRGM/RP-61821-FR. p 99, 16 ill., 18 ann

Cauchi H, Nakache SD et al (1996) Dossier : la réutilisation des eaux usées après épuration. TSM 2:81-118

Chafidz A, Al-Zahrani S, Al-Otaibi MN, Hoong CF, Lai TF, Prabu M (2014) Portable and integrated solar-driven desalination system using membrane distillation for arid remote areas in Saudi Arabia. Desalination 345:36-49

Chocat B, Bertrand-Krajewski J-L, Barraud S (2007) Chapitre: Les eaux pluviales urbaines et les rejets urbains de temps de pluie. Les techniques de 1'Ingénieur. Edition T.I. Doc. W6 800 Ŕ 8-2007, p 17

Dabbagh TA (2001) The management of desalinated water. Desalination 135(1-3):7-23

De Montety V, Radakovitch O, Vallet-Coulomb C, Blavoux B, Hermitte D, Vincent Valles V (2008) Origin of groundwater salinity and hydrogeochemical processes in a confined coastal aquifer: case of the Rhône delta (Southern France). Appl Geochem 23:2337-2349

Devaux I (1999) Intérêts et limites de la mise en place d'un suivi sanitaire dans le cadre de la réutilisation agricole des eaux usées traitées de l'agglomération clermontoise. Thèse univ. Joseph Fourier, Grenoble, p 257

Dillon P (2005) Future management of aquifer recharge. Hydrogeol J 13:313-316

Dillon P, Pavelic P, Toze S, Rinck-Pfeiffer S, Martin R, Knapton A, Pidsley D (2006) Role of aquifer storage in water reuse. Desalination 188:123-134

Dillon P, Pavelic P, Page D, Beringen H, Ward J (2009a) Managed aquifer recharge: an introduction. Waterlines report series $n^{\circ} 13$, February 2009. The National Water Commission, Australian Government

Dillon P, Kumar A, Kookana R, Leijs R, Reed D, Parsons S, Ingleton G (2009b) Managed aquifer recharge: risks to groundwater dependent ecosystems. A review. Water for a healthy country flagship report to land and water, May 2009. The National Water Commission, Australian Government

Feitelson E, Rosenthal G (2012) Desalination, space and power: the ramifications of Israel's changing water geography. Geoforum 43(2):272-284

Foster S, Chilton J, Nijsten G-J, Richts A (2013) Groundwater, a global focus on the 'local resource'. Curr Opin Environ Sustain 5(6):685-695

Giuntoli I, Renard B, Vidal J-P, Bard A (2013) Low flows in France and their relationship to largescale climate indices. J Hydrol 482:105-118

Gleeson T, Wada Y, Bierkens MFP, van Beek LPH (2012) Water balance of global aquifers revealed by groundwater footprint. Nature 488:197-200

Haeber RH, Waller DH (1987) Water quality of rainwater collection systems in the Eastern Caribbean. Third international rainwater catchment systems conference proceedings. http:// www.eng.warwick.ac.uk/ircsa/

Hunter KS, Wang YF, Van Cappellen P (1998) Kinetic modeling of microbially-driven redox chemistry of subsurface environments: coupling transport, microbial metabolism and geochemistry. J Hydrol 209:53-80

IPCC (2014) Climate change 2014: synthesis report. Contribution of working groups I, II and III to the fifth assessment report of the intergovernmental panel on climate change [Core Writing Team, RK Pachauri and LA Meyer (eds)]. IPCC, Geneva, p 151

Johnson JS, Baker LA, Fox P (1999) Geochemical transformations during artificial groundwater recharge: soil-water interactions of inorganic constituents. Water Res 33:196-206

Joss A, Keller E, Alder AC et al (2005) Rermoval of pharmaceuticals and fragrances in biological wastewater treatment. Water Res 39:3139-3152

Khan S, Mushtaq S, Hanjra MA, Schaeffer J (2008) Estimating potential costs and gains from an aquifer storage and recovery program in Australia. Agric Water Manag 95(4):477-488

Kloppmann W, Aharoni A, Chikurel H, Dillon P, Gaus I, Guttman J, Kraitzer T, Kremer S, Masciopinto C, Miotlinski K, Pavelic P, Pettenati M, Picot-Colbeaux G (2012) Use of 
groundwater models for prediction and optimisation of the behaviour of MAR sites. In: Christian K, Thomas W, Peter D (eds) Water reclamation technologies for safe managed aquifer recharge. IWA Publishing, London, pp 311-349

Kümmerer K, Steger-Hartmann T, Meyer M (1997) Biodegradability of the anti-tumout agent ifosafamide and its occurrence in hospital effluents and communal sewage. Water Res $31: 2705-2710$

Lapworth DJ, Baran N, Stuart ME, Ward RS (2012) Emerging organic contaminants in groundwater: a review of sources, fate and occurrence. Environ Pollut 163:287-303

Le Coustumer (2008) Colmatage et rétention des éléments traces métalliques dans les systèmes d'infiltration des eaux pluviales. Thèse de Docteur de l'INSA de Lyon et de Monash University, p 427

Levantesi C, La Mantia R, Masciopinto C, Böckelmann U, Ayuso-Gabella M-N, Salgot M, Tandoi V, Van Houtte E, Wintgens T, Grohmann E (2010) Quantification of pathogenic microorganisms and microbial indicators in three wastewater reclamation and managed aquifer recharge facilities in Europe. Sci Total Environ 40(21):4923-4930

MEDDE (2011) Plan national d'adaptation de la France aux effets du changement climatique 2011 Ŕ 2015. Juillet 2011. www.developpement-durable.gouv.fr

MEDDE (2012a) Mise en oeuvre de la directive cadre sur l'eau : position de la France en Europe en 2009. Observation et statistiques $n^{\circ} 367$. Nov 2012, p 10. www.statistiques.developpementdurable.gouv.fr

MEDDE (2012b) Guide d'évaluation de l'état quantitatif des masses d'eau souterraine. Annexe V de la circulaire relative à l'application de l'arrêté du 17 décembre 2008 établissant les critères d'évaluation et les modalités de détermination de l'état des eaux souterraines et des tendances significatives et durables de dégradation de l'état chimique des eaux souterraines NOR : [DEVL1227826C]. Sept 2012, p 26

MEDDE (2013) Synthèse du projet Explore 2070. Hydrologie souterraine. http://www. developpement-durable.gouv.fr/Evaluation-des-strategies-d.html

Miquel G (2003) La qualité de l'eau et de l'assainissement en France. Rapport de l'Office parlementaire d'évaluation des choix scientifiques et technologiques, Sénat n²15, Assemblée Nationale $\mathrm{n}^{\circ} 705,2$ tomes

Moatty N (2001) Water management and desalination in Israel. Desalination 136(1-3):101-104

Ollivier P, Surdyk N, Azaroual M, Besnard K, Casanova J, Rampnoux N (2013) Linking water quality changes to geochemical processes occurring in a reactive soil column during treated wastewater infiltration using a large-scale pilot experiment: Insights into Mn behavior. Chem Geol 356:109-125

Page D, Dillon P, Vanderzalm J, Bekele E, Barry K, Miotlinski K, Levett K (2010) Managed aquifer recharge case study risk assessments. CSIRO water for a healthy country flagship report series, ISSN: 1835-095X

Palomar P, Losada IJ (2010) Desalination in Spain: recent developments and recommendations. Desalination 255(1-3):97-106

Petalas C, Lambrakis N (2006) Simulation of intense salinization phenomena in coastal aquifers the case of the coastal aquifers of trace. J Hydrol 324:51-64

Pettenati M, Croiset N, Casanova J, Azaroual M, Besnard K, Rampnoux N (2012) Optimisation of waste water treatments through combined geomaterials and natural soil filter: modelling tools. J Water Reuse Desalin 2(4):185-193

Pettenati M, Perrin J, Pauwels H, Ahmed S (2013) Simulating fluoride evolution in groundwater using a reactive multicomponent transient transport model: application to a crystalline aquifer of Southern India. Appl Geochem 29:102-116

Pyne D (2005) Aquifer storage recovery. A guide to groundwater recharge through wells. CRC Press, Boca Raton, p 620

Pyne RDG (2006) Aquifer storage recovery: a guide to groundwater recharge through wells, 2nd edn. Published by ASR Press, Florida 
Rinck-Pfeiffer SM, Ragusa S, Szajnbok P, Vandevelde T (2000) Interrelationships between biological, chemical and physical processes as an analog to clogging in aquifer storage and recovery (ASR) wells. Water Res 34:2110-2118

Roux J-C (1995) The evolution of groundwater quality in France: perspectives for enduring use for human consumption. Sci Total Environ 171(1-3):3-16

Shah T (2014) Towards a Managed Aquifer Recharge strategy for Gujarat, India: an economist's dialogue with hydro-geologists. J Hydrol. Available online 20 Dec 2013, ISSN 0022-1694. doi:10.1016/j.jhydrol.2013.12.022.

Shatat M, Worall M, Riffat S (2013) Opportunities for solar water desalination worldwide: review. Sustain Cities Soc 9:67-80

SOeS (2012) - Les prélèvements en eau en 2009 et leurs évolutions depuis 10 ans. Chiffres \& Statistiques $\mathrm{N}^{\circ} 290$, p 4

Steger-Hartmann T, Kümmerer K, Schecker J (1996) Trace analysis of the antineoplasics ifosfamide and cyclophosphamide in sewage water by two-step solid phase extraction and GS-MS. J Chromat A 726:179-184

Ternes TA, Stumpf M, Scuppert B et al (1998) Simultaneous determination of antiseptics and acidic drugs in sewage and river water. Wom Wasser 90:295-309

USEPA (2004) Guidelines for water reuse. U.S. Environmental Protection Agency, Report No. EPA/625/R-04/108, Cincinnati, p 445

USEPA (2012) Guidelines for water reuse. EPA/600/R-12/618. National risk management research laboratory office of research and development, U.S. Agency for International Development, Cincinnati, p 643

Vernoux JF, Buchet R, Blum A, James O (2010) Améliorer la protection des captages d'eau souterraine destinée à la consommation humaine. Editions du BRGM, p 66. ISBN 978-2-71592484-0 BRGM

Werner AD, Vincent MB, Post EA, Vandenbohede A, Lu C, Ataie-Ashtiani B, Simmons CT, Barry DA (2013) Seawater intrusion processes, investigation and management: recent advances and future challenges. Adv Water Resour 51:3-26

Wintgens T, Hochstrat R, Kazner C, Jeffrey P, Jefferson B, Melin T (2012) Managed aquifer recharge as a component of sustainable water strategies-a brief guidance for EU policies. In: Kazner C, Wintgens T, Dillon P (eds) Water reclamation technologies for safe managed aquifer recharge. IWA Publishin, London, pp 411-429. ISBN 9781843393443

World Health Organization (WHO) (2006a) Guidelines for the safe use of wastewater, Excreta and Greywater, volume 2: wastewater use in agriculture. WHO, Geneva

World Health Organization (WHO) (2006b) Guidelines for the safe use of wastewater, Excreta and Greywater, volume 4: excreta and greywater use in agriculture. WHO, Geneva

Wuilleumier A, Seguin JJ (2003) Réalimentation artificielle des aquifères en France. Une Synthèse. Rapport final BRGM/RP-55063-FR, p 119

Yu JT, Bouwer EJ, Coelhan M (2006) Occurrence and biodegradability studies of selected pharmaceuticals and personal care products in sewage effluent. Agric Water Manag 86:72-80

Zwiener C, Seeger S, Glauner T et al (2002) Metabolites from the biodegradation of pharmaceutical residues of ibuprofen in biofilm reactor and batch experiment. Anal Bioanal Chem 372:569-575 